\title{
Region-Wise Usage of Banking Services - A study of Gujarat
}

\author{
Dr. Jeniskumar P. Chauhan, Ph.D. G.H. Patel PG Institute of Business Management, \\ Sardar Patel University, India, Email- chauhanjenisp@gmail.com
}

\section{Dr. Yogesh C. Joshi, Dean, Faculty of management and Director, G.H. Patel Postgraduate Institute of Business Management, Sardar Patel University Vallabh Vidyanagar, Anand, 388120, Gujarat}

\begin{abstract}
Financial services actively contribute to the humane \& economic development of the nation. Financial services lead to social and economic safety hence, each \& every individual should be provided with affordable institutional financial products/services popularly called "Financial Inclusion". Despite witnessing substantial progress in financial sector reforms in India, it is overwhelming to note that nearly half of the rural households even today do not have any access to any source of funds (savings/credit) - institutional or otherwise. Hardly one-fourth of the rural households are assisted by banks. Hence the major task before banks are to bring most of those excluded, i.e. 75 percent of the rural households, under the mainstream of formal financial services.
\end{abstract}

There is a need for the formal financial system to look at increasing financial literacy and financial counseling. As a part of corporate social responsibility now a day's Indian banks and financial market players should actively look at promoting such programs. Financial products\& services are identified as basic banking services like deposits accounts, institutional loans, access to payment, remittance facilities $\&$ also life $\&$ non-life insurance services. The present paper is an attempt to capture the region-wise usage of banking services. The study collected data of 900 respondents from five regions of Gujarat i.e. South Gujarat, North Gujarat, Central Gujarat, Saurashtra, and Kachchh. The study used a five-point Likert scale agreement method to understand the usage of banking services. Also, the study captured the demographic profile of respondents from. The primary data collected through a structure questionnaire

Keywords - Financial Inclusion, Banking products and services, Region-wise, Financial Literacy, Economic Development, Gujarat.

\section{INTRODUCTION}

The concept of financial inclusion and its proper implementation has come a long way since the last two decades and the results are also quite fair. Access to appropriate financial services can significantly improve the day-to-day management of finances and individuals as well. For example, bills for daily utilities (municipality, water, electricity, telephone etc.) can be more easily paid by using cheques or through internet banking, rather than standing in the long queue in the offices of the service. Another example is to withdraw money from the banking account its easier to use ATM card rather than standing in queue in bank office. Financial inclusion broadens the resource base of the financial system by developing a culture of savings among the large rural populations and plays a crucial role in the process of economic development.

A bank account also provides a range of other financial products and services such as short term credit facilities, overdraft facilities, and credit cards. Further, a number of other financial products, such as insurance and pension products, necessarily require access to a bank account. Though the Indian economy, though achieved a high growth momentum during 2003-04 to 2007-08, could not bring down unemployment and poverty to tolerable levels. To overcome to challenge of penetration, Reserve Bank of India (RBI) has begun the preparation for driving the next stage of financial inclusion, seeking to enhance the penetration of insurance and pension coverage besides bridging the gaps in traditional banking services in the country's rural hinterland.

\section{OBJECTIVE}

To understand the usage of banking facility provided by financial sector.

\section{MeThodology}

All the rural respondent of Gujarat is considered under the population. To have equal representation of the state, the study classified into 5 regions of Gujarat, viz. North, Kutchh, Saurashtra, South, and Central Gujarat. To attain the objective, the survey has been conducted in 5 regions of 
Gujarat. The primary data through structured questionnaire have been used for the study. From each region, two districts were chosen based on rural population i.e. one district is from the highest rural population and one district is from the lowest rural population. Two taluka i.e. one is the highest rural population and one is the lowest rural population were identified among the selected districts. A total of 18 taluka were selected for the study and from each Taluka 50 respondents have been conveniently chosen. Hence the total of 900 rural respondents have been surveyed.

\section{ANALYSIS AND INTERPRETATION}

Table 1: Cross tabulation between age group and region

\begin{tabular}{|c|c|c|c|c|c|c|}
\hline \multirow[t]{2}{*}{ Age } & \multicolumn{5}{|c|}{ Region (\%) } & \multirow[t]{2}{*}{ Total } \\
\hline & Kachchh & $\begin{array}{l}\text { North } \\
\text { Gujarat }\end{array}$ & Saurashtra & $\begin{array}{l}\text { South } \\
\text { Gujarat }\end{array}$ & $\begin{array}{l}\text { Central } \\
\text { Gujarat }\end{array}$ & \\
\hline $\begin{array}{l}18 \mathrm{yrs} \\
\text { to } 25 \\
\mathrm{yrs}\end{array}$ & .0 & 6.0 & 14.5 & 1.0 & 2.0 & 5.2 \\
\hline $\begin{array}{l}26 \mathrm{yrs} \\
\text { to } 35 \\
\mathrm{yrs}\end{array}$ & 47.0 & 22.0 & 32.0 & 41.0 & 33.5 & 33.8 \\
\hline $\begin{array}{l}36 \mathrm{yrs} \\
\text { to } 45 \\
\mathrm{yrs}\end{array}$ & 36.0 & 42.5 & 41.0 & 40.5 & 43.5 & 41.2 \\
\hline $\begin{array}{l}46 \mathrm{yrs} \\
\text { to } 55 \\
\mathrm{yrs}\end{array}$ & 15.0 & 24.5 & 8.0 & 14.0 & 17.0 & 15.8 \\
\hline $\begin{array}{l}56 \text { yrs } \\
\text { and } \\
\text { above }\end{array}$ & 2.0 & 5.0 & 4.5 & 3.5 & 4.0 & 4.0 \\
\hline
\end{tabular}

It was found from the above table that in Kachchh majority of 47 percent of respondents are from the age group of 26 to 35 years followed by 42.5 percent of respondents are from the age group of 36 to 45 years in North Gujarat. The overall scenario shows that 41.2 percent of respondents are from the age group of 36 to 45 years.

Table 2: Cross tabulation between education and region

\begin{tabular}{|l|l|l|l|l|l|l|}
\hline Education & \multicolumn{4}{|l|}{ Region (\%) } & $\begin{array}{l}\text { Tota } \\
1\end{array}$ \\
\hline & $\begin{array}{l}\text { Kachch } \\
\mathrm{h}\end{array}$ & $\begin{array}{l}\text { North } \\
\text { Gujara } \\
\mathrm{t}\end{array}$ & $\begin{array}{l}\text { Saurashtr } \\
\mathrm{a}\end{array}$ & $\begin{array}{l}\text { South } \\
\text { Gujara } \\
\mathrm{t}\end{array}$ & $\begin{array}{l}\text { Centra } \\
1 \\
\text { Gujara } \\
\mathrm{t}\end{array}$ & \\
\hline Illiterate & 9.0 & 16.5 & 11.5 & 13.0 & 11.0 & 12.6 \\
\hline $\begin{array}{l}\text { Std.12th } \\
\text { and above }\end{array}$ & 56.0 & 53.0 & 36.5 & 41.0 & 45.5 & 45.3 \\
\hline Graduate & 35.0 & 23.5 & 31.5 & 37.5 & 37.0 & 32.7 \\
\hline $\begin{array}{l}\text { Post } \\
\text { graduate }\end{array}$ & .0 & 2.5 & 12.0 & 1.0 & 1.5 & 3.8 \\
\hline $\begin{array}{l}\text { Diploma/I } \\
\text { TI }\end{array}$ & .0 & 4.5 & 8.5 & 7.5 & 5.0 & 5.7 \\
\hline
\end{tabular}

It was noticed that in the Kachchh region there are no single respondents studied up to postgraduate or diploma/ITI and 9 percent of respondents are illiterate hence there is a need for education in the Kachch region. In North Gujarat and South Gujarat 16.5 per cent and 13 per cent respondent are illiterate. Hence there is also a need of education in these two regions. Overall 12.6 per cent of respondents are illiterate and only 3.8 percent of respondents are studied up to postgraduate..

Table 3: Cross tabulation between occupation and region

\begin{tabular}{|l|l|l|l|l|l|l|}
\hline $\begin{array}{l}\text { Occupatio } \\
\text { n }\end{array}$ & \multicolumn{4}{|l|}{ Region (\%) } & \multicolumn{2}{l|}{} \\
\hline $\mathrm{h}$ & $\begin{array}{l}\text { Kachch } \\
\text { Gujara } \\
\mathrm{t}\end{array}$ & $\begin{array}{l}\text { Saurashtr } \\
\mathrm{a}\end{array}$ & $\begin{array}{l}\text { South } \\
\text { Gujara } \\
\mathrm{t}\end{array}$ & $\begin{array}{l}\text { Centra } \\
1 \\
\text { Gujara } \\
\mathrm{t}\end{array}$ & Total \\
\hline Business & 5.0 & 20.5 & 21.5 & 6.0 & 12.5 & $\begin{array}{l}14 . \\
0\end{array}$ \\
\hline $\begin{array}{l}\text { Gov.Servic } \\
\mathrm{e}\end{array}$ & 1.0 & 4.5 & 12.5 & 6.5 & 7.5 & 7.0 \\
\hline $\begin{array}{l}\text { Private } \\
\text { service }\end{array}$ & 16.0 & 6.0 & 25.5 & 21.5 & 15.5 & $\begin{array}{l}17 . \\
0\end{array}$ \\
\hline $\begin{array}{l}\text { Profession } \\
\text { al }\end{array}$ & 16.0 & 8.0 & 6.5 & 8.0 & 10.5 & 9.1 \\
\hline Retired & 2.0 & 1.5 & 1.0 & 1.0 & .0 & 1.0 \\
\hline Housewife & 5.0 & 7.5 & 16.0 & 14.0 & 15.5 & $\begin{array}{l}12 . \\
3\end{array}$ \\
\hline $\begin{array}{l}\text { Agricultura } \\
\text { l }\end{array}$ & 55.0 & 48.0 & 15.0 & 40.0 & 36.0 & $\begin{array}{l}37 . \\
0\end{array}$ \\
\hline Any other & .0 & 4.0 & 2.0 & 3.0 & 2.5 & 2.6 \\
\hline
\end{tabular}

The above data shows that in kachch majority 55 percent of respondents are farmers and associated with the agricultural activities followed by 48 percent of respondents in North Gujarat, 40 percent in South Gujarat, and 36 percent in Central Gujarat are related to agricultural activities. Interestingly it was noticed that in Saurashtra majority 25.5 percent of respondents belong to private services. However overall majority 37 percent of respondents are farmers and related to agricultural activities as the data are collected from rural areas of Gujarat.

\section{Usage of Banking Services}

The usage of banking services is categorized into five statements viz. 1) Save and withdraw money frequently, 2) Frequently use credit and repayment facilities of the bank, 3) I am using a bank for the payment of insurance premium, 4) I am using banking services because the interest charged by the bank on advance is economical than charged by the money lenders and 5) Financial inclusion helps my family to learn about financial services.

Based on the above statement's respondents were asked about to show their agreement level in a five-point Likert scale where 1 stands for strongly disagree, 2 stands for disagreeing, 3 stands for neither agree nor disagree, 4 for agree and 5 stands for strongly agree. The following data represents the region-wise distribution of the above five statements. 
Table 4:

\begin{tabular}{|l|l|l|l|l|l|l|}
\hline \multicolumn{2}{|l|}{ Save and withdraw money frequently } \\
\hline $\mathrm{h}$ & $\begin{array}{l}\text { Kachch } \\
\text { Gujara } \\
\mathrm{t}\end{array}$ & $\begin{array}{l}\text { Saurashtr } \\
\mathrm{a}\end{array}$ & $\begin{array}{l}\text { South } \\
\text { Gujara } \\
\mathrm{t}\end{array}$ & $\begin{array}{l}\text { Centra } \\
\text { Gujara } \\
\mathrm{t}\end{array}$ & $\begin{array}{l}\text { Tota } \\
1\end{array}$ \\
\hline $\begin{array}{l}\text { Strongly } \\
\text { disagree }\end{array}$ & & & $\mathbf{1 7 . 9}$ & $\mathbf{. 5}$ & & $\mathbf{4 . 0}$ \\
\hline $\begin{array}{l}\text { Disagre } \\
\mathrm{e}\end{array}$ & & $\mathbf{2 8 . 0}$ & $\mathbf{9 . 7}$ & $\mathbf{7 . 0}$ & $\mathbf{1 3 . 5}$ & $\mathbf{1 2 . 9}$ \\
\hline $\begin{array}{l}\text { Neither } \\
\text { agree } \\
\text { nor } \\
\text { disagree }\end{array}$ & $\mathbf{6 . 0}$ & $\mathbf{1 6 . 5}$ & $\mathbf{3 4 . 2}$ & $\mathbf{3 0 . 5}$ & $\mathbf{2 8 . 5}$ & $\mathbf{2 5 . 0}$ \\
\hline Agree & $\mathbf{7 0 . 0}$ & $\mathbf{4 4 . 5}$ & $\mathbf{3 1 . 1}$ & $\mathbf{4 7 . 0}$ & $\mathbf{4 5 . 5}$ & $\mathbf{4 5 . 2}$ \\
\hline $\begin{array}{l}\text { Strongly } \\
\text { agree }\end{array}$ & $\mathbf{2 4 . 0}$ & $\mathbf{1 1 . 0}$ & $\mathbf{7 . 1}$ & $\mathbf{1 5 . 0}$ & $\mathbf{1 2 . 5}$ & $\mathbf{1 2 . 8}$ \\
\hline Total & $\mathbf{1 0 0 . 0}$ & $\mathbf{1 0 0 . 0}$ & $\mathbf{1 0 0 . 0}$ & $\mathbf{1 0 0 . 0}$ & $\mathbf{1 0 0 . 0}$ & $\mathbf{1 0 0 . 0}$ \\
\hline
\end{tabular}

The above table despites that in Kachchh majority 70 percent of respondents agree with the statement that they save and withdraw money frequently. Likewise in North Gujarat, 44.5 percent, South Gujarat 47 percent, and in Central Gujarat 45.5 percent of respondents are agree with the statement. While in Saurashtra majority 34.2 percent of respondents neither agree nor disagree with the statement.

Table 5:

\begin{tabular}{|l|l|l|l|l|l|l|}
\hline \multicolumn{6}{|c|}{ Frequently use credit and repayment facilities of the bank } \\
\hline $\begin{array}{l}\text { Kachch } \\
\mathrm{h}\end{array}$ & $\begin{array}{l}\text { North } \\
\text { Gujara } \\
\mathrm{t}\end{array}$ & $\begin{array}{l}\text { Saurashtr } \\
\mathrm{a}\end{array}$ & $\begin{array}{l}\text { South } \\
\text { Gujara } \\
\mathrm{t}\end{array}$ & $\begin{array}{l}\text { Centra } \\
\text { Gujara } \\
\mathrm{t}\end{array}$ & $\begin{array}{l}\text { Tota } \\
1\end{array}$ \\
\hline $\begin{array}{l}\text { Strongly } \\
\text { disagree }\end{array}$ & & $\mathbf{2 6 . 0}$ & $\mathbf{2 . 8}$ & $\mathbf{2 . 0}$ & $\mathbf{7 . 0}$ & $\mathbf{8 . 5}$ \\
\hline $\begin{array}{l}\text { Disagre } \\
\text { e }\end{array}$ & $\mathbf{8 . 0}$ & $\mathbf{1 6 . 5}$ & $\mathbf{2 4 . 6}$ & $\mathbf{2 2 . 5}$ & $\mathbf{2 6 . 0}$ & $\mathbf{2 0 . 7}$ \\
\hline $\begin{array}{l}\text { Neither } \\
\text { agree } \\
\text { nor } \\
\text { disagree }\end{array}$ & $\mathbf{4 4 . 0}$ & $\mathbf{3 6 . 0}$ & $\mathbf{4 5 . 8}$ & $\mathbf{3 8 . 0}$ & $\mathbf{4 2 . 0}$ & $\mathbf{4 0 . 7}$ \\
\hline Agree & $\mathbf{3 7 . 0}$ & $\mathbf{1 8 . 0}$ & $\mathbf{2 5 . 1}$ & $\mathbf{3 0 . 0}$ & $\mathbf{2 1 . 0}$ & $\mathbf{2 5 . 0}$ \\
\hline $\begin{array}{l}\text { Strongly } \\
\text { agree }\end{array}$ & $\mathbf{1 1 . 0}$ & $\mathbf{3 . 5}$ & $\mathbf{1 . 7}$ & $\mathbf{7 . 5}$ & $\mathbf{4 . 0}$ & $\mathbf{5 . 0}$ \\
\hline Total & $\mathbf{1 0 0 . 0}$ & $\mathbf{1 0 0 . 0}$ & $\mathbf{1 0 0 . 0}$ & $\mathbf{1 0 0 . 0}$ & $\mathbf{1 0 0 . 0}$ & $\mathbf{1 0 0 . 0}$ \\
\hline
\end{tabular}

For the statement frequently use credit and repayment facility of the bank majority 44 percent of respondents neither agree nor disagree with the statement likewise in all other four region majority respondents are neither agree nor disagree.

\section{Conclusion}

The Empirical research outcomes revealed that still some households in the district are marginalized with limited financial services. For achieving complete admittance to financial services there is a necessity for more attention on the distributional and micro dimensions to attain financial inclusion. The study concludes that banking penetration is there with 100 percent and almost all the people having their individual banking accounts. Still there is a need to include these people into financial services example credit/loan, insurance, etc. Interestingly in Ahmedabad district as education and financial literacy level are high both husband and wife are capable to take financial decisions. There is need to enhance financial literacy in Dahod district. The financial literacy of target groups should be the prime objective for the government. Government of India has taken sincere efforts in bringing the citizens of India under the umbrella of formal banking services. But still some segment of the nation is lagging behind even though financial inclusion initiatives are in progressive stage. Rapidly developing technology has also played a pivotal role in bridging the financial divide of the nation. Extensive efforts are needed not only from banks and other financial institutions, but also from an array of other stakeholders including civil society. The need for an objective and a scientific assessment of the progress made in financial inclusion cannot be overlooked.

\section{REFERENCE}

[1] Anonymous. (2003) All India Debt And Investment Survey; Basic Statistical Return of SCBS (Reserve Bank Of India) March, Census Of India, 2001, Central Statistical Organization

[2] Ambarkhane, D., Singh, A. S., \& Venkataramani, B. (2016). Measuring financial inclusion of Indian states. International Journal of Rural Management, 12(1), 72100.

[3] Bihari, S.C. (2011). Financial inclusion-The key to emerging India. Asian Journal of Research in Social Sciences and Humanities, 1(1), 47-66. Retrieved from http://www.aijsh.org/setup/socialscience/paper

[4] Dev, S. M. (2006). Financial inclusion: Issues and challenges. Economic and political weekly, 4310-4313.

[5] Garg, S., \& Agarwal, P. (2014). Financial Inclusion in India-a Review of Initiatives and Achievements. Journal of Business and Management (IOSR-JBM), 16(6), 52-61.

[6] Jeniskumar Chauhan and Yogesh C Joshi (2018). Pradhan Mantri Jan Dhan Yojana (PMJDY): An Initiative towards Including the Excluded People. International Journal For Innovative Research In Multidisciplinary Field. Vol- 4, Issue - 7, July, 25-31

[7] Jeniskumar Chauhan and Yogesh C Joshi (2019). Status and Challenges of Financial Inclusion: An Evidence from Rural Gujarat. International Journal of Advances in Social and Economics, Vol 1, No 5 November

[8] Kaur, M. S., Kaur, M. M., \& Madan, M. P. (2017). Financial Inclusion in India. International Education and Research Journal, 3(5), 655-658. 
[9] Kumar, N. (2013). Financial inclusion and its determinants: evidence from India. Journal of Financial Economic Policy, 5(1), 4-19.

[10] Srijanani, D. (2012). Financial inclusion: Taking banking services to the common man. International Journal of Management and Business Studies, 2(3), 5458.

[11] Sujlana P. and Kiran C (2018). A Study on Status of Financial Inclusion in India. International Journal of Management Studies, Vol.-V, Issue -2(3), April, 96104

[12] Ranjani, K. S., \& Bapat, V. (2015). Deepening Financial Inclusion Beyond Account Opening: Road Ahead for Banks. Business Perspectives and Research, 3(1), 52-65.

[13] Tamilarasu, D. A. (2014). Role of Banking sectors on financial inclusion development in India-An analysis. Galaxy International Interdisciplinary Research Journal, 2(2), 272-276

[14] Chakrabarty K.C (2011). Financial Inclusion: A Road India Needs to Travel, RBI Bulletin, November, 2011. Chakrabarty, K. C. (2013). Financial Inclusion in India - Journey So Far and Way Forward. Keynote Address at the Finance Inclusion Conclave. Organized by CNBC TV, 18.

[15] International Monetory Fund (2016). Financial Access Survey. $\quad$ Retrieved from https://www.imf.org/en/News/Articles/2016/10/03/PR1 6441-IMF-Releases-the-2016-Financial-Access-Survey

[16] Ministry of Finance (2016). Overview and Progress on Financial Inclusion. Retrieved from https://financialservices.gov.in/sites/default/files/Overv iew $\% 20$ and $\% 20$ Progress $\% 20$ on $\% 20$ Financial\%20Inclu sion\%20.pdf

[17] Reserve Bank of India (various years). Report on Trend and Progress of Banking in India. Retrieved from https://www.rbi.org.in/scripts/AnnualPublications.aspx ?head=Trend $\% 20$ and $\% 20$ Progress $\% 20$ of $\% 20$ Banking $\% 20$ in\%20India 